WITALIJ BARABASZ

(Grodno)

\title{
"ОТ ЧАСТНЫХ ИНЦИДЕНТОВ К ПЛАНОМЕРНОЙ БОРЬБЕ“. СОВЕТСКАЯ ПОЛИТИКА ПРОТИВ ПОЛЬСКОГО ПОДПОЛЬЯ НА ТЕРРИТОРИИ ПОЛЕСЬЯ В ПЕРИОД ГИТЛЕРОВСКОЙ ОККУПАЦИИ
}

ІІроблема советско-польских отношений на территории юго-западных районов Беларуси в период гитлеровской оккупации не получила широкого освещения в исторической литературе. Менее активный интерес к этому вопросу вызван тем, что советско-польская конфронтация в белорусском Полесье не имела такого масштаба в сравнении с территориями Виленского и Новогрудского округов АК. Специфика обстановки в Брестской и Іинской областях заключалась в значительно меньшим сосредоточении польского населения и, соответственно, в отсутствии широкой социальной базы для деятельности польского подполья. Вместе с тем, на примере данного региона также можно проследить эволюцию советской политики в отношении польского подполья в годы войны.

В 1941-1942 гг. руководство СССР, исходя из соглашений с польским эмигрантским правительством, не выступало открыто против польского подполья и, чтобы не обострять с ним отношений, сознательно воздерживалось от активизации советского партизанского движения в Западной Беларуси. Советские партизаны в западных областях не пользовались и значительной поддержкой местного населения. Типичным примером, характеризующим обстановку того периода, служит деятельность парти- 
занского отряда, состоящего из партийно-комсомольского актива Гинской области под командованием Бернштейна. Как отмечал в докладной записке ІІинскому обкому КII(6)Б член этого отряда А. Рохлин, один из главных недостатков заключался в отсутствии в отряде выходцев из местного населения. Это лишало его баз снабжения и постоянной связи, которая позволяла бы получать данные о действиях противника. Население не поддерживало партизан и пряталось при их появлении, чтобы не навлечь на себя подозрения, а также сообщало немцам. Из-за невозможности отряда действовать без средств снабжения и поддержки со стороны местных жителей А.Рохлин просил разрешения отпустить коммунистов и комсомольцев в Красную армию1.

В схожей ситуации оказался партизанский отряд под командованием В. Коржа, образованный в 1941 г. по поручению Пинского обкома КІІ(б)Б из коммунистов и комсомольцев г.Пинска. Отряд сразу столкнулся с серьезными трудностями, поскольку в районах его деятельности, по словам В.Коржа, организовывались „бандитские группы из бывших польских шпионов и диверсантов (...) и начали действовать вместе с немцами против напих активистов, бойцов и командиров, выходивших из окружения на восток. Так происходило в Ленинском, Ганцевичском, Лунинецком и других районах. Видя такую обстановку в западных районах, мы решили перебазироваться в Житковичский район Полесской области, граничагций с Ленинским районом Пинской области". Далее В.Корж сообщал, что у населения был такой страх, что оно боялось не только встретиться с партизанами, но даже знать что-либо о партизанах. На территории, по которой проходил отряд В. Коржа никаких других партизанских отрядов и групп не было, а те которые были созданы, перешли за линию фронта. Отсутствовало там и влияние коммунистической партии. Только весной 1942 г. отряд В. Коржа смог вернуться и возобновить борьбу на территории Пинской области².

Разветвленная сеть шпионажа и частые облавы, в которых наряду с немцами, участвовали и местные жители Брестской области, воспрепятствовали деятельности весной 1942 г. советской партизанской группе во главе с И. Шубитидзе ${ }^{3}$.

В таких сложных условиях работа советского руководства проводилась в ограниченных масштабах. В „Плане развития партизанского движения

\footnotetext{
${ }^{1}$ Национальный архив Республики Беларусь (далее: НАРБ), ф. 4, оп. 33а, д. 8, л. 75-76.

${ }^{2}$ Там же, ф. 4, оп. 33а, д. 189, л. 47-65.
} 
и действий партизанских отрядов зимой 1942-1943 гг. по Белорусской ССР" начальник Белорусского штаба партизанского движения (БІІІПД) П. Калинин излагал планировавшиеся мероприятия по областям. Для Брестской и Белостокской областей предполагалось: „В целях усиления партизанского движения в районах с преобладающим польским населением (Гайновский, Высоковский, Семятичский и Брестский) отобрать специальную группу партийных работников, знаюцих язык и условия работы в этих районах"4.

В интересах антифашистской борьбы, как правило, не запрегцалась совместная работа с подпольем АК, но вместе с тем давались указания вести разведку в её организациях. На территории Брестской области в начале 1942 г. советским подполыцикам стало известно о польских конспиративных организациях. Однако первоначально вступать с ними в контакты опасались из-за отсутствия указаний свыше. И только после одобрения секретаря ЦК КП(б)Б И. Ганенко Брестский подпольный „Комитет борьбы с немецкими оккупантами" установил широкие связи с польскими подпольными организациями и служацими, работавшими в немецких учреждениях на территории Брестской, Барановичской и Белостокской областей. Польские подполыцики снабжали советских антифашистов оружием и боеприпасами, а также бумагой для типографии. Поляки предупреждали о готовяцихся арестах и облавах, передавали ценные разведсведения о гитлеровцах и их агентах. По свидетельству одного из руководителей „Комитета" И. Жижко, при встречах с польскими подполыциками, „(...) мы говорили, что советское правительство имеет договор с польским правительством (...) Какая будет Польша, где будут границы Польши - нас это не интересует. Поэтому есть советское правительство и польское правительство, которые договорятся насчет Польши, насчет границ, а у нас сейчас в порядке дня стоит обцая борьба с немецкими оккупантами".

В целом следует признать, что советско-польское сотрудничество на территории Беларуси, вызванное необходимостью общего сосуцествования, носило неформальный характер и происходило в ограниченных масштабах.

\footnotetext{
${ }^{3}$ Там же, ф. 3500, ол. 4, д. 284, л. 45, История возникновения Пинской партизанской бригады ІІинского соединения (бригады И. ІІубитидзе).

' Российский государственный архив социально-политической истории (далес: РГАСПИ), ф. 69, оп. 1, д. 125, л. 17.

${ }^{5}$ НАРБ, ф. 4, оп. 33а, д. 528, л. 46-48; ф. 750, оп. 1, д. 114, л. 25-27.
} 
Из-за серьёзных противоречий, в первую очередь проблемы будущей советско-польской границы, отношения между правительствами СССР и Польши постоянно ухудшались. После наметившегося в 1943 г. перелома на фронте в пользу СССР советское правительство стремилось к расширению своего влияния на Восточную и Центральную Европу. Руководство СССР берет курс на радикальное усиление советского партизанского движения в Западной Беларуси. Этому вопросу были посвящены решения V Пленума ЦК КП(б)Б, состоявшегося в Москве 26-28 февраля 1943 г. Пленум рассмотрел вопрос „Об обстановке и задачах работы партийных органов и партийных организаций в оккупированных районах Беларуси". Прежде всего было решено усилить руководяццую роль партийных организаций партизанским движением в Беларуси. Ставилась задача образования подпольных партийных областных, городских и районных комитетов и центров ${ }^{6}$. Важное значение придавалось работе с польским населением и польским подпольем. Выступая на Пленуме, начальник Центрального штаба партизанского движения (ЦІШПД) П. Пономаренко указывал: „(...) Задача наша - развивать работу в западных областях, насадить там конспиративные центры, ничего общего не иметь с поляками. Они убивают наших представителей, или будут убивать. Как только откроете, что вы представитељь партийного органа, что вы против фашистов, они вас обманут. Поляков в партизанские отряды нужно принимать с огромным ограничением и с отбором. Ко всем, которые вызывают подозрение, что это агенты националистических польских организаций, нужно относиться осторожно. Если они хотят бороться с немцами - пусть борются, но себя не раскрывайте. Наиболее преданную часть польского населения можно привлекать к работе, но с болыной проверкой. Есть провокаторы, которые хотят столкнуть нас с польским населением. Мы не должны остаться в хвосте событий и не терять влияния среди польских антифашистов".

Разрыв официальных советско-польских отношений был неизбежен. Как подходящий предлог, чтобы избавиться от „неудобного союзника", И.Сталин использовал „Катынское дело”. Правительство В. Сикорского было обвинено в сотрудничестве с гитлеровцами, исходя из чего, 25 апреля 1943 г. СССР прервал с ним дипломатические отношения. Период сотрудничества двух правительств сменяется периодом конфронтации.

' Там же, ф. 4, оп. 33а. д. 146, л. 4.

7 Tам же, ф. 4, on. 20, д. 213, л. 279. 
Линию февральского пленума продолжали решения LLK КП(6)Б, принятые 22 июня 1943 г., - постановление „О мероприятиях по дальнейшему развертыванию партизанского движения в западных областях Белоруссии" и секретное письмо „О военно-политической работе в западных областях БССР"в. В этих документах определялись организационные задачи, направленные на преобразование партизанского движения в западных областях Беларуси в массовое всенародное движение. Прежде всего предполагалось усилить агитационно-политическую работу среди населения и исключить влияние антисоветского польского подполья. Ставилась задача, наряду с комитетами КП(б)Б и ЛКСМБ, создания во всех районах Западной Беларуси партизанских отрядов. В Белостокскую и Брестскую области предписывалось перебросить из других областей Беларуси 40 партизанских отрядов - по одному в каждый район. В секретном письме содержалась детальная инструкция, в соответствии с которой советские формирования были обязаны подавлять польское подполье, несмотря на проводимую им антифашистскую борьбу. В противовес АК из поляков, согласных уважать интересы СССР, в составе советских бригад следовало организовывать польские отряды.

Формы и методы военно-политической деятельности в западных областях Беларуси продолжали обсуждаться советскими руководителями и в дальнейшим. В конце июня 1943 г. секретарь ЦК КП(б)Б И.Ганенко обратился к П. Пономаренко с личным письмом: „(...) На заседании бюро ЦК от 24 июня [1943 г. - В.Б.] был поднят вопрос о распространении организационной формы Брестского комитета борьбы с немецкими оккупантами на западные области БССР. Это предложение не встретило поддержки, только не моей, я беру на себя смелость еце раз поднять этот вопрос перед Вами по следующим мотивам: Время, отделяющее освобождение западных областей БССР от начала второй Отечественной войны было явно недостаточным для радикального перевоспитания местного населения, которое свыше 20 лет подвергалось „воспитанию” польских националистов. Не секрет, что среди значительной части местного населения западных областей Беларуси сохранились в большей или меньшей степени различного рода пережитки религиозные, национал-шовинистические, антиколхозные, антисемитские и т.д., в силу чего эти люди не склонны безоговорочно подчиняться непосредственному руководству партийных подпольных

\footnotetext{
' Гам же, ф. 4, оп. 3, А. 1243, л. 64, 78-90.
} 
огранов. Это, в свою очередь, создает почву для работы польских националистических организаций. В то же время этих людей объединяет со всеми советскими людьми общая ненависть к немцам. (...) Следует подчеркнуть, что недостаточно развернутой связью подпольных партийных органов с местным населением, в частности в городах, и совершенно неудовлетворительным обеспечением нашей агитационной литературой из центра пользуются немецкие фашисты, нацдемовцы, поляки и другие сектанты, пытаясь создавать массовые организации, соответствующие им по духу". На основании опыта деятельности „Брестского антифашистского комитета" и „Могилевского комитета содействия Красной Армии” И. Ганенко обосновывал оправданным создание „массовых беспартийных подпольных антифашистских организаций при условии, когда ими руководит партия через коммунистов и проверенных беспартийных патриотов"9.

В целом И. Ганенко реалистичнее других советских функционеров оценивал обстановку в Западной Беларуси, однако там уже полным ходом шло образование руководящих органов партийного подполья. Весной 1943 года было завершено создание подпольных обкомов КП(б)Б. В апреле 1943 года был образован Брестский обком. Пинский обком был воссоздан еце в августе 1942 г. К осени 1943 г. в основном образованы подпольные партийные органы районного звена. В Брестской области в 1943 г. действовало 8 райкомов, в Пинской - один горком и 11 райкомов ${ }^{10}$. Одновременно происходил процесс формирования подпольных органов ЛКСМБ ${ }^{11}$.

Начиная с весны 1943 г. мероприятия советского руководства привели к быстрому росту партизанских сил в западных областях Беларуси. В докладной П. Пономаренко И.Сталину от 23 ноября 1943 г. сообщалось, что с лета этого года в Западную Беларусь из восточных районов было направлено „более 15 партизанских отрядов и бригад, специально укомплектованных, имеющих в своей среде преданных поляков и средства печатной пропаганды". Это позволило в сравнении с АК создать на территории западных областей республики крупное превосходство сил. Здесь насчитывалось 185 советских партизанских отрядов, имеющих в своем составе 25835 партизан, в т.ч. 9704 партизан - на территории Брестской и Іиинской областей ${ }^{12}$.

\footnotetext{
${ }^{9}$ РГАСІІИ, ф. 625, on. 1, д. 25, n. 464-467.

10 Всенародная борьба в Белоруссии против немецко-фашистских захватчихов в годы Великой Отечественной войны: В 3-х т., Минск 1985, т. 2, с. 65.

"Там же, c. 85-95.

${ }_{12}$ РГАСПИ, Ф. 625, оn. 1, д. 67, л. 356-358.
} 
К зиме 1943-1944 гг. в Западную Беларусь прибыло 16 крупных партизанских формирований, общей численностыо почти 8 тыс. человеков ${ }^{13}$. По другим сведениям, только в мае - ноябре 1943 г. из восточных в западные области республики было передислоцировано 12 тыс. партизан ${ }^{14}$. Переброска партизанских формирований продолжалась в конце 1943 - в 1944 г. На территории Брестской области из 11 действующих бригад 4 прибыло из других областей. При этом последние численно превосходили местные, поскольку включали равное с ними количество отрядов - по 13. Наряду с этим в области было создано 40 отрядов, не входивших в состав бригад, и 4 отдельных отряда переброшено из-за границы области ${ }^{15}$.

Из 9 бригад, действующих на территории Пинской области, из восточных районов прибыло 2. Местных бригадных отрядов насчитывалось 21, переброшенных в бригадах - 6. Отдельных отрядов в области было образовано 17, прибывших извне - $5^{16}$.

Они заняли предписанные им дислокации. Общая численность советских партизан в Западной Беларуси в течение 1943 г. увеличилась более чем в 3 раза и составила 36852 чеюовеков ${ }^{17}$. Личный состав партизанских формирований Брестской области к концу года насчитывал около 7,5 тыс. бойцов, то есть втрое больше, чем в начале года ${ }^{18}$. Общая численность партизанских сил в годы войны на территории Брестской области составляла свыше 14 тыс. $^{19}$ В Пинской области в начале 1943 г. числилось более 1,2 тыс. партизан. К концу года их стало почти в 4 раза болыше ${ }^{20}$. На день освобождения от гитлеровцев в Пинской области насчитывалось более 8,5 тыс. партизан ${ }^{21}$.

Таким образом, с учетом того, что в состав подполья Полесского округа АК на 1 марта 1944 г. входило 4272 человека ${ }^{22}$, в юго-западных областях Беларуси было достигнуто значительное превосходство советских сил над польскими.

\footnotetext{
"Всенародиая борьба в Белоруссии..., т. 2, с. 328.

14 Краткая справха о подпольнох партийньх организациях и партизанском движении в БССР. Состояние на 15 апреля 1944 2., НАРБ, ф. 4, оn. 29, д. 27, л. 91

15 Нартизанские формирования Белоруссии в годы Великой Отечественной войны (июнь 1941 - ияоль 1944), Минск 1983, с. 120-121.

${ }^{16}$ Там же, с. 602-603.

17 Всенародиая борьба в Белоруссии..., т. 2, с. 185.

${ }_{18}$ Там же, c. 184.

19 ПІартизанские формирования Белоруссии..., с. 123.

${ }^{20}$ Всенародиая борьба в Белоруссии..., т. 2, с. 183.

${ }^{21}$ ІІартизанские формирования Белоруссии..., с. 601.
} 
Одновременно развертывалась широкая агитационно-пропагандистская работа. На польском языке распространялись листовки, сводки Совинфорбюро, сообщения ТАСС ${ }^{23}$, статьи центральных советских газет, материалы, посвященные польским проблемам и др. Только за 1943 г. Брестским антифашистским комитетом было распространено на польском языке: сводок - 13432 экземпляра, листовок - 724 экземпляра, другого различного материала - 2169 экземпляров ${ }^{24}$.

Дальнейшие мероприятия в Западной Беларуси, изложенные в докладной П. Пономаренко от 23 ноября 1943 г. предполагали:

„1. Расширить и углубить партизанское движение и работу подпольных антифашистских организаций. Передислоцировать необходимое количество организационных групп и отрядов из Восточной Беларуси в пограничные области Западной Беларуси, где они должны обрасти местными людьми и распространить свое влияние.

2. Вооружить проверенные партизанские резервы, для чего перебросить 8-10 тыс. автоматов и винтовок.

3. Усилить массово-политическую работу среди населения, выпуск газет и распространение газеты Союза польских патриотов среди польского населения.

4. Польские отряды и группы, действующие в Западной Беларуси и нападающие на советских партизан, уничтожать. Все другие группы, занимающие выжидательную позицию, дискредитировать, разоружать и рассеивать, командный состав уничтожать.

Ввиду того, что изложенное выше является вопросом важным, т.к. означает переход от частных инцидентов к планомерной борьбе с польским враждебным националистическим подпольем, прошу ваших указаний"25.

Предложенные П. Пономаренко мероприятия были одобрены советским руководством и активно реализовывались. Выполняя указания ЦК КП(б)Б, руководители советских формирований прилагали усилия для организации отдельных польских взводов, рот, а затем и целых отрядов. Их стремились противопоставить нараставшему влиянию среди поляков Армии Крайовой. Для образования польских отрядов на территорию

\footnotetext{
${ }^{22}$ Холу6 Ч., История Јолесского охруга ZWZЈАК. Краткий очерк, Врест, 1993, с. 13.

${ }^{23}$ Совинфорбюро - Советское ииформационное бюро; ТАСС - Телеграфное агенство Советского Союза.

24 НАРБ, ф. 1333, on. 1, д. 17, л. 15.

${ }^{25}$ РГАСІІИ, ф. 625, on. 1, д. 67, л. 357-358.
} 
Беларуси из „Большой земли" забрасывались организационные разведывательно-диверсионные группы, в которых было много поляков - выходцев из западных областей республики. Активное участие в этой деятельности принимал Союз польских патриотов. Однако результаты оказались незначительными. Достоверно известно о существовании в составе БШПД летом 1943 - в июле 1944 г. пяти польских отрядов, а также около десятка польских групп (рот) в советских формированиях ${ }^{26}$. Наряду с этим, несколько образованных польских отрядов в 1944 г. было переправлено из территории Беларуси в Польшу.

Обстановка в юго-западных районах Беларуси обострялась в результате жестокого террора со стороны украинских националистов по отношению к польскому населению. Чтобы найти какую-то защиту от террора УПА поляки обращались за помощью даже к немцам в организации самообороны ${ }^{27}$. Но большая часть из них искала спасения в партизанской борьбе. В составе Пинского партизанского соединения было создано два польских отряда. С января 1944 г. в бригаде им. Куйбышева действовал польский отряд под названием „Логишинский”. Отрядом, численностью 36 партизан, командовал А. Жилевиче2. Но самый крупный польский отряд в Западной Беларуси, в котором сражалось 282 партизана, отряд им. Костюшко был образован в конце июля 1943 г. в составе бригады им. Молотова, затем Пинской партизанской бригады. Возглавлял отряд Ч. Вархоцкий, а с конца 1943 г. Ч. Клим ${ }^{29}$.

Участие поляков в советском подпольном и партизанском движении, а также формирование из их числа национальных подразделений в советской историографии представлялось как проявление „глубоко интернационального характера антифашистского сопротивления на территории Беларуси, который питала нерушимая братская дружба народов СССР ${ }^{\text {зо }}$. Однако на примере отряда им. Костюшко видно, что не все было так однозначно. Командование Пинской партизанской бригады сразу столкнулось с серьезными трудностями в политико-воспитательной работе с личным

${ }_{26}^{26}$ В. В. Бара6аш, Поляки в антифашистской боробе на территории Беларуси (1941-1941 г2.), Іроцно 1998, с. 56-63.

${ }^{27}$ M. Juchniewicz, Polacy w radzieckim ruchu podziemnym i partyzanckim 1941-1944, Warszawa 1973, s. 250.

${ }^{28}$ Ibid, s. 352-355; НАРБ, ф. 1407, оп. 1, д. 114, л. 4-5.

${ }^{29}$ НАРБ, ф. 1407, оп. 1, д. 180а, л. 24-34; М. Juchniewicz, Polacy w radzieckim ruchu..., s. 253.

${ }^{\circ}$ В едином строю. Воспоминаяия участииков партизанского двикения в Белоруссии, Минск 1970, c. 14. 
составом отряда. В его рядах находились люди, обремененные различными комплексами и предубеждениями, часто на основе пережитого собственного опыта без симпатии относившиеся к советской власти. Если общая цель борьбы с оккупантами не вызывала возражений, то предлагаемая советским руководством будущая граница между СССР и Польшей не встречала понимания у значительной части поляков ${ }^{31}$. В докладной записке „О политико-моральном состоянии партизанского отряда им. Костюшко Пинской партизанской бригады" по состоянию на 25 апреля 1944 г. уполномоченный особого отдела отряда им. Костюшко сообщал о превалировании „мелкобуржуазных настроений". Он отмечал, что среди личного состава найдется 20-30\% лояльно относящихся к советской власти. Остальные были настроены антисоветски, симпатизировали польскому эмигрантскому правительству и выступали за независимую и демократическую Польшу. Агентура особого отдела доносила о частых антисоветских высказываниях партизан, вкліочая и командиров отряда Ч. Вархоцкого и Ч. Клима, о желании уйти воевать за Буг ${ }^{32}$. Ч. Клима обвиняли в том, что он „(..) ориентируется на политику англо-американскую. (...) В отряде, где нет советских людей, где огромное большинство пришло лишь для того, чтобы спасти жизнь от украинских националистов (не от немцев), вместе с таким командиром как Клим трудно воспитать людей в здоровом советском духе. Есть в отряде люди, которых можно перевоспитать и сделать нашими людьми, здравомыслящими, но не под руководством Клима. Клим - польский вояка, воспитанный в буржуазной армии"з3.

Примечательно, что антисоветские настроения были замечены и у командира другого отряда им. Костюшко, первого польского-советского отряда на территории Западной Украины Р. Сатановского. В докладной от 18 августа 1943 г. на имя П. Пономаренко начальника 7-го отдела 2-го управления НКГБ СССР Г. Жукова сообщалось: „По имеющимся у нас данным, находящийся в Москве командир польского отряда Роберт Сатановский и его жена Болеслава Сатановская (...) по своим убеждениям являются польскими националистами, резко враждебно настроены к Ванде Василевской и считагот ее предателем польского народа, допускают клеветнические

\footnotetext{
${ }^{31}$ M. Juchniewicz, Polacy w radzieckim ruchu..., s. 254-255.

${ }^{32}$ НАРБ, ф. 1364, оп. 1, д. 22, л. 124-126.

${ }^{33}$ Там же, $ф .3500$, оп. 2, д. 34, л. 11, Донесение начальнику особого отдела Іиинской партизанской бригады, командиру бригады от источника „Грозного" от 19 апреля 1944 г.
} 
высказывания по адресу руководителей советского государства. (...) Если ЦШПД считает возможным произвести переброску Сатановского в тыл противника, считал бы целесообразным его жену оставить на территории Советского Союза"з4.

Соответственно у советского руководства в отношении польских подразделений заметным было проявление недоверия. По утверждению бывшего партизана отряда им. Костюшко Х. Краевского, ни один из партизан отряда не был награжден партизанской медалью ${ }^{35}$. В литературе есть сведения, что командир Ч. Клим за успешные боевые действия своего отряда в марте 1944 г. в районе р. Припять получил орден Красного Знамени Однако сама постановка вопроса свидетельствует, что партизаны отряда им. Костюшко, проведшие много успешных боевых акций (всего более 100), не были заслуженно отмечены советским командованием.

Следует отметить, что на территории Беларуси политика советских властей отличалась жестким характером в отношении как польского национального движения, так и в целом к польским формированиям. Во многом это было определено личной позицией I-го секретаря ЦК КП(б)Б П. Пономаренко. Выступая против создания самостоятельных польских бригад, которые бы подчинялись Союзу польских патриотов (СПП), П. Пономаренко в телеграмме от 11 сентября 1943 г. разъяснял своим подчиненным партизанским командирам: „Руководство партизанским движением на всей территории Беларуси, в том числе и польского населения, проживающего на территории западных областей, реализуется партийными организациями КП(б)Б. Союз польских патриотов есть организация, действующая только для Польши и с Белоруссией не имеющая никакой связи"

Характерно, что в западных областях Украины наряду с советскими партизанами действовали и отряды Гвардии Людовой. На территории Беларуси полякам было разрешено бороться только в рядах советских партизан. Созданные в республике при участии СПП польские отряды затем направлялись в Польшу. В Пинской партизанской бригаде кроме отряда им. Костюшко в 1944 г. было образовано еще три польских отряда в количестве

* PГАСІІИ, ф. 69, ол. 1, д. 748, л. 141.

"I IIAPb, ф. 1407, оn. 1, д. 180а, л. 3.

${ }^{36} \mathrm{M}$. Juchniewicz, Polacy w radzieckim ruchu..., s.350.

${ }^{37}$ HAPb, ф. 3500, on. 23, д. 36, л. 479. 
170 чел. Для их создания из Москвы была переброшена организационная группа, связанная с СПП. В 1944 г. новые польские отряды были переправлены за Буг для продолжения борьбы на территории Полыни ${ }^{38}$.

Решения, принятые советским руководством в первой половине 1943 г. об организационной и военно-политической работе, обсуждались затем на заседаниях подпольных обкомов и райкомов партии, собраниях первичных парторганизаций партизанских отрядов Беларуси ${ }^{39}$. Так, в мае - летом 1943 г. на собраниях парторганизаций отрядов Пинского партизанского соединения изучался курс советского руководства в отношении польского правительства и польского движения Сопротивления. Обсуждались вопросы вербовки польского населения для совместной антифашистской борьбы, создания польских партизанских групп в составе советских отрядов, подавления польского подполья ${ }^{40}$. На партийном собрании 22 июля 1943 г. в отряде имени Суворова Пинской партизанской бригады командующий бригады Г. Шубитидзе указывал, что полицию в г. Пинске (известную связью с польским подпольем), необходимо использовать в наших интересах „(..) и с ними вести пока мирную политику, чтобы не поставить их и польский народ против себя". Было решено вопрос о дальнейшей тактике в отношении пинской полиции поставить перед штабом бригады".

Наряду с этим, известно, что уже весной 1943 г. советские партизаны применяли жесткие меры против польского подполья. Его разработкой в первую очередь занимались создаваемые в тот же период в советских партизанских бригадах и отрядах специальные ячейки НКГБ - особые отделы и особые отделения. Ими проводились репрессии в отношении организаций и лиц, которые не поддерживали советскую власть. В апреле-мае 1943 г. на территории Западной Беларуси резко возросло число расстрелянных советскими партизанами членов конспирации АК. Вероятно это было связано с прибытием из-за линии фронта руководяццх кадров западнобелорусских обкомов. Эти советские функционеры, осведомленные в указа-

${ }_{38}^{38}$ Там же, ф. 1364, оп. 1, д. 18, л. 224.

${ }^{39}$ Всенародная борьба в Белоруссии..., т. 2, с. 53.

${ }^{10}$ НАРБ, Ф. 1364, оп.1, д. 20, л. 8-9, ІІротокол $\$ 07$ собрания партийцой организации ири отряде им. Суворова 5/V - 1943 r.; Там же, л. 14, ІІротокол 280 Общего собрания членов и кандидатов парторганизации партизанского отряда им. ЛІазо 2/VII - 1943 г.; Там же, л. 61 -62, IІротокол No9 собрания партийной организации при отряде им. Суворова 22/VII - 1943 r.

"Там же, ф. 1364, оп. 1, д. 20, л 62. 
ниях высшего партийного руководства в отношении польского подполья, выдали соответствуюшие распоряжения ${ }^{42}$. Когда в болыпинстве попытки подчинения советскому руководству организаций АК или разложения их изнутри не удались, переходили к открытой конфронтации. Чаце всего удар наносился по „головам” - выявляли и расстреливали руководителей подполья, парализуя его деятельность.

В апреле 1943 г. были получены агентурные данные, что в Лунинецком и Ленинском районах ІІинской области появились неизвестные люди, которые вели „разговоры о польской республике”. Пинским обкомом КП(б)Б было дано задание особым отделам партизанских отрядов области оставить всю работу и узнать, что это за люди и какая цель их деятельности. Было установлено, что группу возглавлял помецик Козловский, учитель по профессии, бывший капитан польской армии. Эта группа в количестве 9 человек была захвачена особым отделом штаба Пинского соединения в ночь на 9 мая 1943 г. и расстреляна ${ }^{43}$.

На заседании бюро ЦК КГІ(б)Б 24 июня 1943 г. П. Пономаренко дал директиву советскому подполью и партизанским отрядам выявлять польские организации и всячески ставить их под удар немецких оккупантов, не стесняясь методами ${ }^{44}$. И указания начальника ЦШІД выполнялись точно. Особым отделом Пинской партизанской бригады продолжалась разработка польской подпольной антифашистской организации в г. IИнске. В конце 1943 г. была предпринята попытка перетянуть польское подполье на свою сторону, для чего в переговорах использовались партизаны отряда им. Костюпко. Однако предложения о сотрудничестве были отклонены пинским подпольем. Как было заявлено: „Мы в дальнейшим с польским партизанским отрядом [им. Костюшко - В. Б.] связи иметь никакой не будем, т.к. они пропитаны большевизмом, а мы знаем, что большевики не меныние враги, чем немцы”. В результате действиями особого отдела список польской организации оказался в гестапо. В ІПинске было арестовано 250 поляков, служивіших у немцев, в т.ч. руководитель конспирации Матиевский. Имея данные о связи с этой организацией польских подпольциков, входивіних в полицию г. Логишина во главе с комендантом полиции Татаревичем, тот же особый отдел в январе 1944 г. предложил Татаревичу

12 Z. Boradyn, Niemen rzeka niezgody. Polsko-sowiecka wojna part yzancka na Nowogrodczyznie 1943-1944, Warszawa 1999, s. 100.

${ }^{43}$ Там же, $\phi .4$, on. 29, д. 9, л. 41.

41 Там же, ф. 4, on. 33а, д. 254, л. 46-47. 
со всеми полицейскими перейти к партизанам. Татаревич отказался и был расстрелян. Список из 200 поляков логишинской полиции благодаря особому отделу стал также известен гестапо. Из них $80 \%$ было расстреляно ${ }^{45}$. В целом, в 1943 г. Полесский округ АК понес значительные потери как в составе конспирации, так и в рядах диверсионных и партизанских отрядов от действий гитлеровцев и советской разведки и партизан ${ }^{46}$.

Следует признать, что польское подполье, польское население платили тем же. По утверждению руководства Брестского антифашистского комитета, польские конспиративные организации со времени прихода немцев принимали участие в уничтожении советского актива. В конце 1942 года по указанию польского подполья полицейские - поляки составили списки оставшегося советского актива, которых затем посредством гитлеровцев ликвидировали ${ }^{47}$. В разведдонесении от 31 января 1944 г. командования бригады им. Пономаренко Брестского партизанского соединения сообщалось о том, что местные поляки вели разведку о местонахождении партизан и доносили немцам, занимались шпионажем и травлей "советских юодей”, компроментировали их перед немцами. Приводился список поляков, благодаря которым немцами с 1941 было расстреляно до 30 „советских граждан”. Далее разведдонесение информировало: „(..) Польская молодежь из Березовского района различными способами старается уехать за Буг, пишут до немцев просьбы и заявления. В основном их заставляот уезжать следующие причины: а) нежелание прихода Красной Армии, б) боятся остаться на месте, т.к. они натворили столько „мудреных дел”, что им Советская власть никогда не простит, в) центр польской подпольной организации „Вольна Польска” находится за Бугом и он перетягивает эту молодежь за Буг”48.

Наличие крупного превосходства в силах позволило советским партизанам осуцествить без значительного сопротивления подавление в юго-западных районах Беларуси отрядов АК. В 1943-1944 гг., по меньшей мере, там был уничтожен один польский отряд и три разоружены. После

is Там же, ф. 3500, оп. 4, д. 284, л. 76-78.

16 Ч. Холуб, указ. соч., с. 12.

${ }^{47}$ НАРБ, $ф .1333$, оп. 1, д. 17, л. 16, Отчет о работе Брестского антифашистского комитета за 1943 г. секретаря Брестского антифашистского комитета Максима, 30 января 1944 r.

4 НАРБ, ф. 3500, оп. 2, д. 32, л. 7, 14, Разведцонесение от 31 января 1944 г. командира партизанской бригады им. ІІономареико Брестского партизанского соединеиия Сенькина и помощиика начальника штаба по разведке Ригина. 
разоружения польские партизаны были принудительно включены в состав советских формирований ${ }^{49}$.

Главное командование АК пыталось противодействовать вовлечению поляков в ряды советских партизан. В директиве, изданной 13 марта 1943 г. формированиям АК, главной целью в отношении советских партизан признавалась необходимость перехватить знамя польской патриотической акции. Ставилась задача перетягивания в ряды АК поляков, силой обстоятельств вынужденных скрываться в лесах. Для этого предписывалось усилить в советских формированиях пропаганду, что на территории Полыши действуют польские партизанские отряды, в которых есть место для граждан Речи Посполитой ${ }^{50}$.

Несмотря на относительно небольшую численность, влияние польского подполья на местное население Полесья было довольно значительным. В отчете о работе Брестского антифашистского комитета за 1943 г. его руководство сообщало, что на территории Брестской области „нет ни одного малого местечка, где бы не было ячейки польской организации”. Польское подполье имело также поддержку как в польских, так и в белорусских деревнях, преимущественно среди зажиточньх слоев ${ }^{51}$. На основе анализа агентурных сведений командир партизанского отряда „Советская Белоруссия” бригады им. Пономаренко Брестской области Власов в сообщении от 6 мая 1944 г. отмечал, что пропаганда польского подполья имела влияние не только на польское, но и на православное белорусское население. По его оценкам, „(...) 5\% белорусского православного населения стоит на стороне поляков и готово к ним примкнуть для борьбы за освобождение Полыни"52. Следует отметить, что речь шла о районах с преобладаюцим белорусским населением.

Известно, что в целом белорусы играли существенную роль в деятельности Армии Крайовой на территории Западной Беларуси. В ее рядах вместе с белорусами-католиками, состояло много и православных ${ }^{53}$. Политика советской власти в Западной Беларуси в 1939-1941 гг. вызвала негативное к ней отношение части белорусов, которые стали выступать за восстановление прежнего польского государства.

49 Ч. Холу6, указ. соч., с. 20-21; T. Gasztold, Rozkaz zabić przyszedl z Moskwy, s. 43; Z. Gnat-Wieteska, 30 Polska Dywizja Piechoty Armii Krajowej, s. 13.

${ }^{50}$ M. Fieldorf, L. Zachuta, General „Nil” August Emil Fieldorf, Warszawa 1993, s. 312-313.

${ }^{5_{1}}$ НАРБ, $\phi .1333$, on. 1, д. 17, л. 15.

${ }^{52}$ Там же, ф. 1401, 01I. 1, А. $200,11.83$.

53 J. Prawdić-Szlaski, Nowogródczyzna w walce 1940-1945, London 1976, s. 192, 229; K. Krajewski, Na Ziemi Nowogródzkiej. "Nów" - Nowogródzki Okręg AK, Warszawa 1997, s. 112. 
В сложившейся ситуации довольно трудно было реализовывать намеченный курс советского руководства. Брестский антифашистский комитет столкнулся с невозможностью создания партийных организаций среди местного населения, и вместе с Брестским обкомом партии направил свою деятельность на образование сети антифашистских организаций ${ }^{54}$. В вышеупомянутом отчете Брестского антифашистского комитета за 1943 г. признавалось, что со стороны комитета сделано очень мало в разложении польских подпольных организаций и внедрении в них своих пюдей. Это объяснялось тем, что советским руководством своевременно не были даны соответствующие указания, и комитет опасался проводить данную работу самостоятельно. „(...) Чрезмерная осторожность в отношении польского населения оторвала комитет от основных вопросов, интересующих польское население, и дала возможность польским реакционерам быть полными хозяевами на польской улице". Делался вывод, что советские антифашисты не только не установили влияние среди поляков, не подорвали авторитет польского эмигрантского правительства, но и не имели существенных результатов в разработке польских подпольных организаций, учитывая их совершенную конспирацию5.

О широком влиянии польского подполья сообщало 24 мая 1944 г. командование Пинского партизанского соединения. Проводившее ранее с ним активную борьбу, партизанское руководство было вынуждено признать, что принимать меры изоляции и изъятия людей, причастных к активной деятельности против советской власти стало затруднительным из-за его влияния на население. Чтобы исправить данную ситуацию проводились агитационно-пропагандистские мероприятия. Однако ощущался недостаток количества соответствующей литературы ${ }^{56}$.

Таким образом, несмотря на активные мероприятия органов советской власти и значительное численное преимущество (особенно в юго-западных районах Беларуси) подчиненных им вооруженных сил, не удалось полностью подавить польское подполье в период немецкой оккупации. С установлением советской власти потребовалось еще десятелетие для его искоренения в ходе крупномасштабных операций органов госбезопасности и частей Красной армии.

\footnotetext{
44 НАРБ, ф. 1333, оn. 1, д. 17, л. 15.

s5 Там же, ф. 1333, оn. 1, д. 17, л. 16.

s6 Там же, ф. 1364, оn. 1, д. 22, л. 129.
} 


\title{
"From separate incidents to scheduled fight". Soviet policy towards the Polish Underground in the Polesie territory during German occupation
}

\begin{abstract}
Summary
The article presents the origin and objectives of Soviet policy towards Polish population and the Polish Underground in Polesie during German occupation. On the basis of Soviet documents and Polish literature the author presents changes in Soviet policy: from common operation with the Polish Government in exile imposed by the situation at the eastern front line in 1941-1942, through attempts to treat Poles as allies, to conf rontation and decisive actions aiming at the liquidation of the Polish Underground in the subject territory by all possible means. The article includes many new facts excerpted from Soviet archives. Moreover, it emphasizes P.K. Ponomarenko's role in creating anti-Polish policy. It was him who, among other things, recommended denunciating Polish conspirators to Gestapo. The author provides data proving that this suggestion was put into effect.

Anti-Polish policy of Soviet authorities in 1939-1941 made Poles and the Polish Underground treat USSR first as an "ally of our allies" too, but after USRR broke off diplomatic relations with Poland in April 1943 and started to liquidate the Polish Underground on the subject territory, as their enemy as well. The article proves that also Belarusian historians take up subjects so far considered controversial and cease to repeat propaganda evaluations of the Soviet historiography.
\end{abstract}

\section{„Od odosobnionych incydentów do planowej walki”. Radziecka polityka wobec polskiego podziemia na terenach Polesia w okresie okupacji niemieckiej}

\section{Streszczenie}

Artykuł przedstawia genezę i założenia radzieckiej polityki wobec ludności polskiej i polskiego podziemia na Polesiu w okresie okupacji niemieckiej. Na podstawie radzieckich dokumentów oraz polskiej literatury autor przedstawia zmiany $w$ radzieckiej polityce od wymuszonego sytuacją na froncie wschodnim w latach 1941-1942 współdziałania $\mathrm{z}$ polskim rządem na uchodźstwie i próbach 
traktowania Polaków jako sojuszników do konfrontacji i zdecydowanych działań w celu likwidacji wszystkimi sposobami polskiego podziemia na omawianym terenie. Praca zawiera wiele nowych ustaleń faktograficznych zaczerpniętych $\mathrm{z}$ radzieckich archiwów i podkreśla rolę $\mathrm{P}$. K. Ponomarenki $\mathrm{w}$ kreowaniu antypolskiej polityki. To on zalecał m.in. denuncjowanie polskich konspiratorów do gestapo. Autor przytacza dane potwierdzające, że zalecenie to było wykonywane.

Antypolska polityka władz radzieckich w latach 1939-1941 sprawiła, że również Polacy i polskie podziemie traktowało ZSRR początkowo jako „sojusznika naszych sojuszników", a po zerwaniu przez ZSRR w kwietniu 1943 r. stosunków dyplomatycznych $\mathrm{z}$ Polską i przystąpieniu do likwidacji polskiego podziemia na omawianych terenach również jako wroga. Artykuł potwierdza, że także historycy białoruscy podejmują kontrowersyjne dotąd tematy i odchodzą od powtarzania propagandowych ocen radzieckiej historiografii. 